\title{
Innovative Partnership as New Form of Public Procurement in the European Union
}

\author{
Dr. iur. Vitaliy M. Pashkov, PhD Andrii A. Olefir \\ Poltava Law Institute of Yaroslav Mudryi \\ National Law University, Ukraine \\ v.pashkov26.06@ukr.net
}

\begin{abstract}
This article explores a new public procurement procedure - the innovative partnership, its features, stages, advantages and disadvantages, as well as problem points. It has been proven that innovative partnership is a perspective public procurement procedure aimed at encouraging practical development and implementation of innovations by the private sector of the economy, under the control of customers. The innovation partnership has some drawbacks due to the novelty of the procedure and they should be corrected by practice in the future. The "flexibility" of the partnership (considerable freedom of action of the customer) is a positive feature that corresponds to the tendency of de-bureaucratisation. According to this, problems and key tasks of innovative development in the European Union were defined in the context of strengthening of protectionist ideas and impending changes in technological structures. Also, practical recommendations for the successful organisation of an innovative partnership have been proposed in the article.
\end{abstract}

Keywords: innovative partnership, public procurement, government contracts, customers, Directive 2014/24/EU, innovations.

\section{Introduction}

From world experience it is known that a dynamic growth of the economy is possible only on the basis of an innovative growth model and intensive technological renovation of production. For this, first of all, it is necessary to reorient state policy on financial supporting of individual enterprises and industries. Also it would be desirable to create attractive conditions for investing innovation and spreading innovations in 
all sectors of the national economy. To achieve these, it would be necessary to actively involve business entities in innovative activities, combining state and market levels of regulating economic relations.

The EU Member States differ one from another in economic and legal features. In this regard, the processes of innovation development in each of these countries proceeds in different ways. It is known that an important feature of innovation activity is a high level of investments in the development of an innovative product. Besides costs and risks are rapidly growing. The authors show that the EU innovative programmes contribute to the active interaction of the member countries [24, 7]. It is necessary to pay attention to some ratings: (1) Global Innovation Index (2016): first - Switzerland (66.28); second - Sweden (63.57); third - United Kingdom (61.93); fourth - United States of America (61.40); tenth - Germany (57.94); twenty fourth - Estonia (51.73); thirty fourth - Latvia (44.33); thirty sixth - Lithuania (41.76); thirty ninth - Poland (40.22); fifty sixth - Ukraine (35.72) [5]; (2) Gross expenditure (\% of GDP) on R\&D (2014): first - Korea, Rep (4.29); second - Israel (4.11); third - Japan (3.58); fourth Finland (3.17); fifth - Sweden (3.16); sixth - Denmark (3.08); tenth - United States of America (2.73); fifteenth - China (2.05); twenty fourth - Estonia (1.43); thirty fourth - Lithuania (1.01); thirty sixth - Poland $(0,94)$; forty eighth - Latvia (0.69); fifty fourth - Ukraine (0.66) [6].

In this regard, the notion "European paradox" emerged to reflect a situation in which European countries have exceptionally high scientific potential, but they poorly implement it in new products, especially in the sphere of high technologies. Therefore, it is especially important to ensure the practical use of the acquired knowledge and hold positions in the creation of new knowledge (fundamental research).

Advanced innovative development becomes very important for the states in the era of changing technological structures. Now we are on the threshold of the fourth way, which will be based on technologies of "cyber physical systems" (Industry 4.0). Industry 4.0 dictates the end of traditional centralised applications for production control. Its vision of ecosystems of smart factories with intelligent and autonomous shop-floor entities is inherently decentralised. Responding to customer demands for tailored products, these plants fuelled by technology enablers such as 3D printing, Internet of Things, Cloud computing, Mobile Devices and Big Data, among others create a totally new environment. As mass production gives way to mass customisation, each product, at the end of the supply chain, has unique characteristics defined by the end customer. The supply chains of Industry 4.0 are highly transparent and integrated $[1,18]$. According to this, "Europe 2020" puts forward three mutually reinforcing priorities: (1) smart growth: developing an economy based on knowledge and innovation; (2) sustainable growth: promoting a more resource efficient, greener and more competitive economy; (3) inclusive growth: fostering a high-employment economy delivering social and territorial cohesion [3]. 
The EU currently has a target of investing $3 \%$ of GDP in R\&D. The target has succeeded in focusing attention on the need for both the public and private sectors to invest in R\&D [3]. The Innovation Union calls for unleashing the public sector's purchasing power to spur innovation through public procurement including precommercial procurement [8]. Public procurement is seen as a tool to achieving the objectives of the Europe 2020 strategy, whilst ensuring the most efficient use of public funds and maintaining an open market [18]. European experts foster the development of "channels of interconnection" between the Horizon 2020 programme and public procurement programmes for innovative products in order to ensure the transformation of $R \& D$ results into innovative products [23]. Public procurement is an important function of a government for several reasons. It has been utilized as an important tool for achieving economic, social and other objectives. In its report to the Congress, the Commission on Government Procurement states: "the magnitude of the Government's outlays for procurement and grants creates opportunities for implementing selected national policies". The World Bank's "Procurement under IBRD Loans and IBRD Credits" specifies following major objectives of public procurement for projects funded by its loans: Encouraging development of indigenous contractors and manufacturers by allowing local buyers to build in a margin of preference for local contractors and manufacturers [11].

Protectionism is a very controversial topic. A country's protectionism will mean the protection of home industries or infant industries. Opponents often argue that no nation has all of the commodities that it needs. Some countries are abundant in certain resources, while others may lack them. For example, Colombia and Brazil have the ideal climate for growing coffee beans. The US is a major consumer of coffee, yet it does not have the suitable climate to grow any of its own. Consequently, this has made Colombia and Brazil big coffee exporters and the US a big coffee importer [16, 354]. Despite the dogmas of the old-fashioned and inconsistent classical economic monetarism that condemns protectionism, it is still necessary to use its opportunities. By the way, in the documents of the European Union, it is noted that Europe will continue to benefit from being one of the most open economies in the world, but the competition from developed and emerging economies is intensifying. Countries such as China or India are heavily investing in research and technology in order to move their industries up the value chain and "leapfrog" into the global economy. This puts pressure on some sectors of our economy to remain competitive [3]. For example, the Law of the People's Republic of China "On Public Procurement" has established the rule that governmental agencies and legal entities with the participation of state capital may purchase domestic goods and services, with the exception of those cases when external goods and services, other things being equal, are not less than $20 \%$ cheaper than domestic goods. The term "internal" should be understood as products, at least $50 \%$ of the cost of which (including raw materials and components) were created in China. Also, in the People's Republic of China, the Plan for the Development of Science and Technology for 2006-2020 has been 
adopted, which provides, inter alia, an indication for the purchase of innovative products exclusively from specialized catalogues. These include the so-called "internal innovations". In order to recognise the product as an internal innovation, its manufacturer must be a Chinese resident and be the owner of corresponding registered trademarks, patents and other intellectual property rights in the territory of the People's Republic of China [7, 10].

\section{Legal Significance and Features of the Innovative Partnership}

In recent years, many countries pay more attention to the public procurement system to ensure innovative development. With nearly a third of public spending used for purchasing goods and services, the Government is uniquely placed to drive innovation in the economy. The challenge for every governmental department is, therefore, to look at innovation as a tool to transform public services and potentially create new markets. Departments should be thinking about procurement strategically and planning ahead [13]. There are two ways how to stimulate innovation: by purchasing ready-made innovative products and placing orders for its development, as well as conducting separate stages of applied research, developing a solution, a prototype, and a limited batch of prototype goods (services). In addition, the main trend, typical for the USA, in the EU countries and China over the past decade has been a gradual tightening of the requirements for the environmental characteristics of the purchased products, the processes of its production and utilisation, which stimulates the introduction of appropriate innovative solutions by the suppliers of products. In the USA, it is established that $95 \%$ of new contracts should provide for the procurement (development) of products that have an advantage over previously purchased in at least one of the following criteria: energy efficiency; water efficiency; production on the basis of biotechnologies using renewable natural resources; non-toxicity or reduced toxicity; friendliness to the ozone layer; use of recycled materials. Similar requirements are established in China [7, 9]. For example, in the EU the main objective of the innovative procurement project "Ecoquip", organised by the Polish hospital of Sucha Beskidzka, was to improve the thermal comfort of patients (shades reducing excessive sunlight in a building facing South). In the procurement procedure, a solution was found in the installation of fixed outward stores covered with solar panels which also led to energy self-sufficiency with zero exploitation costs [10].

If purchasers remain conservative, however, businesses will not be encouraged, or even allowed, to innovate. Therefore, since April 2016 new EU public procurement rules are granting new options to encourage innovation without hampering competition and transparency $[9 ; 15]$. The key aspects of reforming the public procurement system reflected in these directives can be summarised as follows: (1) simplification of bureaucratic procedures and increasing flexibility; (2) clarification of conditions and procedures 
for joint procurement in order to stimulate demand for innovation; (3) increase of the importance of the life cycle cost criterion; (4) forming of the legal framework for the creation of innovative partnerships.

One of the most interesting new ideas in the Directive 2014/24/EU [4] is the Innovative Partnership procedure, which provides a relatively flexible route for the contracting authority to work with a supplier or suppliers to develop innovative goods, services and works. The directive is being transposed into national legislation in most countries now. As the authors mention, "it is an application of the competitive procedure with negotiation to set up a partnership with one or several operators, with additional rules regarding the structure and phasing of contracts" [20]. A new procedure is aimed at offering contracting authorities a tool to act as demanding customers and early adopters of desired innovation [14]. The term "partnership" is not used in a legal sense (such as LLPs, partnerships or limited partnerships) and should be distinguished from European Innovation Partnerships (EIPs) [22].

It is necessary to define such common features of the procurement procedure:

1) the process can only be used in circumstances where the goods, works and services that are sought are innovative [18], with the requirement for the contracting authority to do the following in the procurement documents: identify the need for an innovative product, service or works that cannot be met by purchasing products, services or works already available on the market, and indicate which elements of this description define the minimum requirements to be met by all tenders [22];

2) long-term relationship - a particular innovative product, service or work must be delivered according to the agreed performance levels and costs without the need for a separate procurement procedure;

3) innovation partnerships allow for a phased engagement with single or multiple suppliers [20]. However, the preamble of Directive 2014/24/EU [4] contains an indication that the creation of innovative partnerships with multiple partners can contribute to avoiding consequences in the form of restriction of competition;

4) participants have to carry out research activities;

5) the object of the partnership is not "finished purchasing decisions", the initial work might turn into a prototype or a pilot phase of work, and eventually into a real, live delivery contract [20];

6) the innovation partnership shall set intermediate targets to be attained by the partners and provide for payment of the remuneration in appropriate instalments;

7) the legal framework contains additional rules regarding the structure and phasing of contracts [20]; 
8) the contracting authority shall ensure that the structure of the partnership and, in particular, the duration and value of the different phases reflect the degree of innovation of the proposed solution and the sequence of the research and innovation activities required for the development of an innovative solution not yet available on the market [4];

9) the estimated value of supplies, services or works shall not be disproportionate in relation to the investment required for their development. This requirement seeks to avoid the abuse of the procedure and limit the quantum of the award to an amount that is essential to intensify the development [18];

10) contracting authorities should be enabled to run a tender competition for both the development and the purchase of innovative goods, works or services in a single award process [18]. The last ability may have been the driver for the introduction of this process.

This all assumes the arrangement is commercially attractive both to contracting authorities and economic operators [2]. So, this procedure can be characterised as a highly specialised and flexible. In procurement documents, the contracting authority shall define the arrangements applicable to intellectual property rights. In the case of an innovation partnership with several partners, the contracting authority shall not reveal to other partners solutions proposed or other confidential information communicated by a partner in the framework of the partnership without that partner's agreement. Such agreement shall not take the form of a general waiver but shall be given with reference to the intended communication of specific information [4].

Attention should be paid to the concept of "innovation" to understand the subject of procurement procedure. Innovation is defined in the Directive as the implementation of a new or significantly improved good, service or process, including but not limited to production, building or construction processes, a new marketing method, or a new organisational method in business practices, workplace organisation or external relations inter alia with the purpose to help solve societal challenges or to support the Europe 2020 strategy for smart, sustainable and inclusive growth [4]. According to this information, innovation can be understood as a product that is a fake innovation.

Instead, purchased products must provide economic benefits and contain an element of know-how (inventive). So, innovation is an introduced novation that ensures a qualitative increase in the efficiency of economic processes or products for which there is a market demand. It is very important to understand what innovation is, what we buy and for what purpose. Just a common novelty (without a marketing demand) is not interesting to anyone. Procurement systems should be oriented not at the novelty of products as such, but at achieving specific goals in the field of health, ecology, industry, energy, etc. This is the essence of innovative partnership. Experts also mention that innovation gives the potential to create better value for money by contributing to better quality public services, reduced costs and faster achievement of benefits [13]. 


\section{Stages of Innovation Partnership}

In the past, a contracting authority wishing to run a procurement procedure that combines both development and purchase elements encountered a myriad of difficulties in structuring a competition that did not infringe upon the principles of equal treatment and transparency. The new innovation partnership allows for the combination of development and purchase elements tailored at public requirements, with specific rules in place to ensure equal treatment and transparency.

The innovation partnership process takes place in three phases:

1) the competitive phase takes place at the very beginning of the procedure, when the most suitable partner(s) are selected on the basis of their skills and abilities. The contracts establishing the innovation partnership are awarded using the criteria of the best price-quality ratio proposed;

2) in the next phase, the partner(s) will develop the new solution in collaboration with the contracting authority. This research and development phase can be divided into several stages during which the number of partners may be gradually reduced, depending on whether or not they meet predetermined criteria;

3) in the commercial phase, the partner(s) provide the final results [9].

Other authors investigate this issue more closely and highlight stages and substages: (1) before procurement: (1.1) develop IPP; (1.2) ensure client capability; (1.3) involve supplier early; (1.4) communicate long-term plans to the market; (1.5) have early crossfunctional dialogue (incl. policy, procurement and project staff); (1.6) be responsive to unsolicited proposals; (1.7) decide how best to handle IPR and understand why; (1.8) use output/outcome specification; (1.9) decide whether to allow variant bids; (1.10) consider contracting strategy (incl. use of SMEs; appropriateness of partnering); (1.11) evaluate risks early: business strategy - establish need - develop need - develop procurement strategy; (2) during procurement (evaluation of proposals - evaluate value outputs from proposed innovations; evaluation of risk; evaluate variant bids (if applicable); include appropriate provision for innovation in contract): specification, selection and competitive bidding - award/implement contract; (3) after procurement (risk/reward sharing; manage incentives; continuous improvement via contract and supplier management): manage contract and supplier relationship closure [13].

Competitions under the innovation partnership procedure will be governed by effectively the same rules that will apply to other procurement procedures under the Directives. However, there are certain additional requirements specific to innovation partnership. Some of the key requirements include the following: (1) required solution: the contract notice must set out sufficient information to allow tenderers to identify the nature and scope of the required solution as a whole. It must also set out performance levels and maximum costs to which the resulting products or services must adhere; (2) contract notice: the contracting authority must issue a contract notice in the usual way and the minimum time limit for receipt of requests to participate is 30 days from the day 
which the contract notice is issued; (3) process: it will be in successive stages including (3.1) the research and development of the solution which can take place in several stages, and (3.2) the subsequent supply to the contracting authority of the solution. More than one partner can be identified and partners can then be eliminated as the development work progresses. The partnership will set intermediate targets to be attained by the partners and can provide for payments in appropriate instalments. (4) Selection criteria: criteria must be applied in respect of tenderers' capacity in the field of research and development when selecting candidates. Capacity is distinguished from experience, so as not to rule out the involvement of start-ups. (5) Award phase: whilst the minimum requirements and award criteria are not subject to negotiation, contracting authorities are required to negotiate with tenderers on their tenders to improve their content, save for the final tender. The criteria to award the innovation partnership must always be the most economically advantageous tender with the best price-quality ratio [18].

In addition, the procurement process is carried out according to the following rules: (1) at the first stage (collecting customer information), any economic operator may submit a request to participate in response to a call for competition by providing the "information for qualitative selection that is requested by the contracting authority" [22]. After the first phase (qualification), participants submit their proposals in the form of research and innovation projects; (2) generally, contracting authorities shall negotiate with tenderers the initial and all subsequent tenders submitted by them, except for the final tender, to improve the content thereof [4].

The need for the innovative partnership procedure is due to the fact that the innovation process, especially at its initial stages, is an extremely problematic zone, with a lack of investments. For example, joint venture capital is in an early stage in Romania, and has no visible contribution to the stimulation of R\&D activity. The considerable budgetary funds allotted to the business sector in contrast to the decreasing participation of this sector in GERD leads to the conclusion that the public funds brought about a "substitution effect" instead of the desired "complementary-like effect". The dependency of the business sector on public funding and its decreasing contribution to the total research and development funding attest that it is still not enough consolidated [19, 135].

Under the previous rules, where a contracting authority wishes to run a procurement procedure that combines both development and purchase elements together it encounters a myriad of difficulties in structuring a competition that does not infringe upon the principles of equal treatment and transparency. The innovation partnership introduces express rules in place to seek to ensure equal treatment and transparency [18]. As with the competitive dialogue ten years ago, the innovation partnership will be what the leading contracting authorities make of it. The innovation partnership can in practice lead to something completely new [21]. In general, an innovative partnership can be considered as a result of the evolution of legal forms of other procurement procedures. The trend is the development of a "technological dialogue" with industry, encouraging the industry to submit proposals for developing new or supplying ready-made innovative 
products. Moreover, for example, German experts consider the request for proposals as the most appropriate way to purchase innovative products and note that in this way Germany holds more than $40 \%$ of government purchases $[25,12]$.

\section{Problems of Application of Innovation Partnership}

Despite the fact that there is lack of sufficient practice of applying innovative partnership, there are a number of issues which can arise in practice when using the innovation partnership procedure:

1) as for the new procedure, care should be taken to ensure that the rules are scrupulously followed and applied. All steps should be documented carefully by a contracting authority so that there is a solid audit trail should the procedure ever be challenged. For example, how much research has been done to determine that the relevant products, services or works are not already available on the market; how the market has been defined; whether all of the duties on the contracting authority in connection with innovation partnerships have been considered carefully;

2) preparation and scoping of the project is critical in terms of running a successful and focused negotiation procedure;

3) the optimal approach to the procedure is to use it in a consultative way that requires a contracting authority to have a clear understanding of the strengths and weaknesses of potential solutions; pre-procurement activity is usually the key if the innovation procurement procedure is to be used;

4) a contracting authority needs to appreciate that to run a successful innovation procurement procedure it will have to be well-resourced with good project management in place. Clear decision-making processes are vital, and the areas for negotiation should be well-thought in advance of procurement (there is no need to have a dialogue with bidders on every single aspect of a project);

5) timetables need to be realistic and allow sufficient time for bidders to prepare responses;

6) a contracting authority will need to decide how many stages the negotiation will have (usually progressing from outline solutions to more detailed solutions, further refinement and then final tenders) and at which stages bidders and/or solutions may be removed from the process. A contracting authority will also need to decide which methods are to be used in the negotiation phase (meetings, presentations or written submissions);

7) a contracting authority will need to determine what in fact it considers a solution to be and when it will close the negotiations, thus effectively ending the dialogue/negotiation stage of the procurement process;

8) ensuring well-developed bid documentation and clear evaluation methodologies linked to the bid requirements as the lack of transparency in evaluation methodologies is a major source of complaints and potential challenge [22]. 
While the concept of innovation partnerships has been broadly welcomed, concerns have been raised by some commentators, particularly in relation to the potentially anti-competitive effect of the procedure. This is clearly an area of weakness that could potentially give rise to challenges in a procedure that is not properly managed [18]. The authors mention that the development phase can lead to a meaningful contract without the need for further competition once the innovation is proven [20]. There are other arguments in favour of a possible restriction of competition. In the first selection phase, candidates are filtered by applying selection criteria. This approach seems feasible in "ordinary" procedures, where existing products and services are purchased and where the experience of the candidates is important. The innovation partnership, though the "usual" application of selection criteria, could exclude newcomers where those should actually be welcomed [12].

Another potential exploit of the "investment required for its development" is intellectual property. It is not a secret that many companies are internally organised so that their intellectual property is held on a low-tax jurisdiction and is licensed to subsidiaries elsewhere. In software development, for example, a multinational company takes part in a software development innovation partnership with the contracting authority agreeing to pay $£ 1 \mathrm{M} /$ year for the innovative solution. By coincidence the underlying IP is owned by a subsidiary based in Ireland which licenses it to the English subsidiary for the purposes of this contract for $£ 5 \mathrm{M}$. Presto, we have just easily justified 6-8 years of a contract to cover for the investment cost. Even a tighter definition of $R \& D$ costs would not provide full respite, although it would certainly make the financial shenanigans more difficult to be managed. Fair development costs can be multiple times bigger than the price a single client will pay for a product. Therefore, it would be wrong to anticipate that Microsoft charges the full Windows development cost to a single customer [21].

Some authors argue that the new procedure is ineffective. Probably all that can be done with it related to innovation can be done with competitive dialogue or competitive procedure with negotiation. The innovation partnership is the only procedure where it is stated from the very beginning that it can be run from start to finish with a single supplier. For instance, a supplier with access to a contracting authority offers an innovative solution for a problem, and the contracting authority does not even have to waste money doing a competitive dialogue or a restricted procedure. They can use this new approach, called innovation partnership, legally from the start with a single supplier and this procedure can be used for anything falling under the definition of innovation. The second Trojan horse leg is the duration of the partnership: a resulting partnership can last for a long time before anyone can start asking questions. Also, it includes a limitation on value (already prevalent in the Directive): the value of the contract cannot be disproportionate to the investment required for its development. However, the language is vague enough so that a lot of costs can be attributed to the "investment required for its development". Case in point: adapting the tooling of a factory for a slightly modified product to be produced for a client implies that the investment cost will include not only the adaptation but also the original tooling and eventually the capital costs for the factory [21]. 
So, there are some negative aspects of the innovative partnership:

1) competition can be strictly restricted, because anything can be mentioned under innovation, it can even be corruption; here one participant is possible;

2) these offences can be for years;

3) there is a limitation of such awarding criteria as a price.

The provisions regulating innovation partnership are rather poorly drafted. Despite the criticism, the innovation partnership procedure could be welcomed among public authorities. It is an instrument that has the potential to strongly stimulate the investment by public purchasers in $R \& D$ activities, provided they have the opportunity to directly purchase the resulting products, services or works without the burden of organising a new procedure to this end [14]. This new procedure seems to offer the flexibility to set up a contractual partnership with a limited number of chosen providers, then ask them each to develop component parts of an overall solution to a complex problem, before awarding a delivery contract or contracts to the partners that deliver the most applicable solution at that design stage. It is difficult to find clear examples of when the innovation partnership may be used. However, it could be helpful in designing a technology-based multi-agency business transformation project, or a waste project involving recycling, landfill and waste to energy technologies. Or even in the design and commissioning of innovative surgical techniques [2].

\section{Conclusions}

The innovative partnership is a new and long-range procedure for public procurement aimed at promoting development and innovation by companies under the control of a customer. This procedure is on time. The partnership has some deficiencies that should be corrected in practice. Flexibility of the Innovative Partnership (substantial discretion of the customer) is a positive feature, which meets the move to non-bureaucratic public services.

The benefits of this procedure are as following:

1) possibility of the development of new types of goods and services;

2) market stimulation through the appointment of one or several partners competing to conduct separate research and development activities funded through the contract;

3) choice of most suitable partners for development contracts [17];

4) provision of clearer guidelines for contracting authorities wishing to procure innovative goods, works and services and overcoming the issue of procuring both the development and purchase of these in one award procedure. Given the additional requirements involved, contracting authorities will have to carefully plan and run the procedure to avoid the risk of a procurement challenge [18];

5) this procedure can solve a particular problem tech based startups have in public procurement: access to public contracts and also the ability to develop their products hand in hand with what the customer wants [21]. 
The employment of this new procedure should be based on the following minimum recommendations:

1) the purchasing bodies must ensure full compliance with the principles of transparency, equal treatment, proportionality and non-discrimination governing the public procurement arena, while also ensuring the safeguarding of confidential information and trade secrets communicated by the bidders throughout the conduct of the procedure;

2) the tender documentation should be drafted in a comprehensive manner, covering in detail all the aspects of the procedure (e.g. selection and award criteria, the duration and value of the different phases of the procedure and the envisaged stages of negotiation, arrangements applicable to IPRs, the draft framework agreement etc.);

3) considering the risk of distortion competition by allowing a large deployment of products, services or works, the contracting authorities could envisage limiting the purchase of products, services or works resulting from the conduct of R\&D activities to a limited number, such as, potentially, the first batch thereof;

4) the innovation partnership ought not to be used by contracting authorities in such a way as to prevent, restrict or distort competition and setting up partnerships with several partners could contribute to avoiding such effects; to this extent, clear rules to be followed by the contracting authority to choose which products to purchase in case more products will be successfully developed by several partners at the end of the R\&D phase within the partnership are recommended to be included in the tender documentation [14].

Thus, it is possible to formulate some proposals:

1) to introduce a justified and correct single definition of innovative products for public procurement, because it should not be simply the novelty, but it will get improved characteristics, including environmental, energy according to the profile of the customer;

2) to form a broad legal framework for procurement procedures that facilitate innovations;

3) to consolidate the principle of stimulating innovation in procurement legislation;

4) it is better to fix a customer's responsibility for improper application of procedures and violation of the principle of stimulating innovation (purchase of morally obsolete, energy-inefficient, environmentally hazardous products);

5) the legislator should oblige companies to create and publish plans for the procurement of innovative products. To do this, it is necessary to determine the criteria for "innovativeness" of products;

6) to introduce protectionist measures: selective protection of important projects or the protection of the entire spectrum of domestic production (quotas for innovation, internal innovation procurement programmes, based on the experience of China). 
It is necessary to draw up a priority list (inventory) of products and technologies (at national or local level), which should be formed at the request of developers, manufacturers and suppliers, and not at the request of the executive branch. Any innovative company should become a member of the list, if it made a proposition for inclusion of their products into the register and received a positive opinion of experts. The register can be binding or advisory (information support). It will be extremely useful to counteract fake innovations (for example, cups with two handles, etc.).

\section{Inovatīvā partnerība kā jauna publiskā iepirkuma forma Eiropas Savienībā}

\section{Kopsavilkums}

Šajā rakstā ir izpētìta jauna publiskā iepirkuma procedūra Eiropas Savienībā novatoriska partnerība, t. sk. tās īpašības, posmi, priekšrocības un trūkumi, kā arī problēmas. Ir pierādìts, ka novatoriska partnerība ir perspektīva publiskā iepirkuma procedūra, kuras mērḳis ir veicināt privātā sektora attīstību un inovāciju ieviešanu, ko kontrolē pasūtîtājs. N̦emot vērā procedūras novitāti, inovācijas partnerībai ir daži trūkumi, un nākotnē tos vajadzētu koriĝèt praksē. Partnerības "elastība" (ievērojama klientu rīcības brīvība) ir pozitīva iezīme, kas atbilst debirokratizācijas tendencei. Rakstā definētas galvenās problēmas un attīstības uzdevumi Eiropas Savienībā kontekstā ar protekcionistisko ideju nostiprināšanu un gaidāmajām pārmaiņām tehnologiskajās struktūrās. Ir piedāvāti praktiski ieteikumi veiksmīgai novatoriskas partnerības organizēšanai.

Atslēgvārdi: inovatīvā partnerība, publiskais iepirkums, valdības līgumi, klienti, Direktīva 2014/24/ES, inovācijas.

\section{References}

1. Almada-Lobo, F. The Industry 4.0 revolution and the future of Manufacturing Execution Systems (MES). Journal of Innovation Management, 2015, (4), 16-21.

2. Bennett, J. Innovation partnership - does it offer a genuine breakthrough? Thomson Reuters, Practical Law: Public Sector Blog, 2015. Available from: http://publicsectorblog.practicallaw. com/INNOVATION-PARTNERSHIP-DOES-IT-OFFER-A-GENUINE-BREAKTHROUGH/ [reviewed 2017.06.13.].

3. Communication from the Commission "Europe 2020": A strategy for smart, sustainable and inclusive growth. EUR-lex: Access to European Union law, 2010. Available from: http://eur-lex. europa.eu/legal-content/en/ALL/?uri=CELEX\%3A52010DC2020 [reviewed 2017.06.13.]. 
Vitaliy M. Pashkov, Andrii A. Olefir. Innovative Partnership as New Form of Public Procurement in the European Union

4. Directive 2014/24/EU of the European Parliament and of the Council of 26 February 2014 on public procurement and repealing Directive 2004/18/EC Text with EEA relevance. EUR-Lex: Access to European Union law, 2014. Available from: http://eur-lex.europa.eu/legal-content/EN/ TXT/?uri=CELEX\%3A32014L0024 [reviewed 2017.06.13.].

5. Dutta, S., Lanvin, B., Wunsch-Vincent, S. The Global Innovation Index 2016: Winning with Global Innovation. Cornell University, INSEAD, and the World Intellectual Property Organization, 2016, p. 451. Available from: https://www.globalinnovationindex.org/gii2016-report\# [reviewed 2017.06.13.].

6. GERD: Gross expenditure on R\&D (\% of GDP). The global innovation index, 2014. Available from: https://www.globalinnovationindex.org/gii-2016-report\# [reviewed 2017.06.13.].

7. Gerson, B. D. Government procurement in China. Sentinel, 2010, 7, 3, p. 9-10.

8. Green Paper: from Challenges to Opportunities: towards a Common Strategic Framework for EU Research and Innovation funding. European Commission, 2011. Available from: http:// ec.europa.eu/research/horizon2020/pdf/com_2011_0048_csf_green_paper_en.pdf [reviewed 2017.06.13.].

9. Innovative partnership keep public services up to date. European Commission, Growth: Internal Market, Industry, Entrepreneurship and SMEs, News, 2016. Available from: http://ec.europa.eu/ growth/tools-databases/newsroom/cf/itemdetail.cfm?item_id=8699[reviewed 2017.06.13.].

10. Innovative public procurement can lower pressure on health budgets. European Commission, Growth: Internal Market, Industry, Entrepreneurship and SMEs, News, 2016. Available from: http://ec.europa.eu/growth/tools-databases/newsroom/cf/itemdetail.cfm?item_id=8945 [reviewed 2017.06.13.].

11. Thai, K. V. Challenges in Public Procurement: An International Perspective. Florida Atlantic University, Public Procurement Research Center, Florida: PrAcademics Press, 2005, p. 407.

12. Ortner, R. Innovation Procurement under the new Procurement Directive - a new instrument for national authorities in procuring EO services? BHO Legal, 2015. Available from: http://earsc. org/.../Innovation+Procurement+under+the+new+proc... [reviewed 2017.06.13.].

13. Pearson, I., Drayson, L. Driving innovation through public procurement. The Office of Government Commerce in the United Kingdom, 2009, p.24. Available from: https://procurement-forum.eu/.../BIS_innovationbrochure.pdf [reviewed 2017.06.13.].

14. Piga, G., Tatrai, T. Public Procurement Policy (The Economics of Legal Relationships). Routledge, 2016, p. 242.

15. Procurement of innovation. Legal framework for PPI: procurement of innovation platform. Available from: http://www.innovation-procurement.org/about-ppi/legal-framework [reviewed 2017.06.13.].

16. Fouda, R. A. N. Protectionism and Free Trade: A Country's Glory or Doom? International Journal of Trade, Economics and Finance, 2012, 3 (5) 351-355.

17. Route 3 - Develop Strategy - Procurement Route - Innovation Partnership. Procurement Journey. Available from: https://www.procurementjourney.scot/route-3/route-3-develop-strategy-procurement-route-innovation-partnership [reviewed 2017.06.13.].

18. Rowan, A. The innovation partnership. Eolas Magazine, 2014. Available from: http://www. eolasmagazine.ie/the-innovation-partnership/ [reviewed 2017.06.13.].

19. Sandu, S. Main Issues of R\&D Financing in Romania. Romanian Journal of Economics, 2010, 1, 127-145. 
Vitaliy M. Pashkov, Andrii A. Olefir. Innovative Partnership as New Form

of Public Procurement in the European Union

20. Smith, P. Using Innovation Partnerships to Develop a Challenge to a Monopoly Supplier. Public spend forum Europe, 2015. Available from: http://publicspendforumeurope.com/2015/06/30/ using-innovation-partnerships-to-develop-a-challenge-to-a-monopoly-supplier/ [reviewed 2017.06.13.].

21. Telles, P. Public Contracts Regulations 2015 - Regulation 31. Public Procurement, 2015. Available from: http://www.telles.eu/blog/2015/4/9/public-contracts-regulations-2015-regulation-31 [reviewed 2017.06.13.].

22. The innovation partnership procedure explained. Local Government Lawyer, 2015. Available from: http://www.localgovernmentlawyer.co.uk/index.php?option=com_content\&view=article \&id=23577\%3Athe-innovation-partnership-procedure-explained\&catid=53\%3Aprocurementand-contracts-articles\&Itemid=21 [reviewed 2017.06.13.].

23. Tumer, S. Pre-commercial Procurement and Public Procurement of Innovative Solution. In: SAP Technology and Innovation Platform, Berlin, 2012. Available from: http://docshare04.docshare.tips/files/25019/250196769.pdf [reviewed 2017.06.13.].

24. Varga, A., Schalk, Y., Koike, A., et. al Integrating the effects of geography into EU Cohesion Policy impact modeling: The GMR-approach. [Paper presented at the modeling workshop of the German Section of the European Regional Science Association]. Brussels, 2008, p. 3-27.

25. Weber, M. Procurement of innovation in Germany: political goals and empirical findings. Joint CIIE-CSTP work-shop on demand-led innovation policies. Paris, 2009. p. 1-15. 